\title{
Sacrifice and 'Religion': Modeling Religious Change in the Roman Empire
}

\author{
James B. Rives \\ Department of Classics, University of North Carolina at Chapel Hill, Chapel Hill, NC 27599-3145, USA; \\ jbrives@email.unc.edu
}

Received: 27 October 2018; Accepted: 21 December 2018; Published: 28 December 2018

\begin{abstract}
In this paper I present a model for describing the change in religion that took place during the Roman imperial period, a model that is built around a contrast between orthopraxy and orthodoxy. I begin with a brief survey of the most important earlier models of religious change in the Roman empire, followed by an initial sketch of my own proposed model. In the third and fourth sections I elaborate on this model in more detail by developing it through two brief case studies: the Graeco-Roman practice of animal sacrifice and the nascent Christian discourse around that practice. In analyzing animal sacrifice, I focus on its role in constructing the socio-political and cultural structures of the Roman empire. For the Christian discourse of sacrifice, I limit myself to one particular text, Paul's first letter to the Corinthians, which provides some of the earliest surviving reflections on sacrifice by a Christ-follower. I close with a few comments on some of the limitations as well as the potential of my proposed model.
\end{abstract}

Keywords: animal sacrifice; Graeco-Roman religion; early Christianity; orthopraxy; orthodoxy; Paul

For any medium has the power of imposing its own assumptions on the unwary.

Marshall McLuhan (McLuhan 1964, p. 30)

\section{Introduction}

It is obvious, and was so even to contemporaries, that over the course of the first few centuries $\mathrm{CE}$ there were significant changes in those aspects of Mediterranean culture that we would now label 'religion.' These changes culminated in the 4th century, when the conversion of Constantine and the continued adherence to Christianity on the part of virtually all his successors resulted in the social and political promotion of Christianity and the gradual suppression of most traditional modes of interacting with the divine. How we might best understand these changes is the subject of this essay. ${ }^{1}$ By 'understand' I do not mean anything so ambitious as identifying the underlying causes but simply describing them as precisely as possible or, in other terms, modeling them. My purpose is merely to sketch out a model that I hope can usefully highlight some of the key underlying aspects of these changes. I have been developing this model with the ultimate goal of employing it as the analytical framework for a large-scale study of animal sacrifice in the Roman empire, one that takes it as a focal point for exploring the nature of and the driving forces behind religious change in the Mediterranean

1 Earlier versions of this paper were presented at a workshop on 'Empire and the Media of Religion' at the University of California Los Angeles, the University of Virginia, the University of Michigan and a colloquium on 'Religion before "Religion"' at Bowdoin College. I owe thanks to the audiences on all those occasions for helping me clarify my ideas and hone my analyses. I must also thank William H. Race for his careful reading of an earlier draft and especially Daniel Ullucci for inviting me to contribute it to this volume and providing me with extensive feedback. 
world. $^{2}$ I offer a preliminary sketch of it here as contribution to the central question with which this collection of papers is concerned: how can an analysis of 'sacrifice,' as both a practice and a discourse, aid the study of religion past and present?

In the first section of this essay I provide a brief survey of the most important earlier models of religious change in the Roman empire, followed in the second by an initial sketch of my own proposed model. In the third and fourth sections I elaborate on this model in more detail by developing it through two brief case studies: the Graeco-Roman practice of animal sacrifice and the nascent Christian discourse around that practice. Both these case studies are deliberately limited in scope, in keeping with the overall goals of this essay. As the abundant recent scholarship on the topic has made clear, animal sacrifice was a multi-faceted practice, which can fruitfully be analyzed from a number of angles. I focus here on its role in constructing the socio-political and cultural structures that ordered power relationships in the Roman empire. Likewise, in order to avoid glossing over the complexities of the Christian response, I limit myself to one particular text, Paul's first (extant) letter to the Corinthians, which provides some of the earliest surviving reflections on sacrificial practice by a Christ-follower. I close with a few comments on some of the limitations of my proposed model.

\section{Earlier Models of Religious Change}

The first and most long-lived model for understanding the religious changes of the Roman imperial period had its origins among contemporary Christians. Working within the longstanding Judaean tradition of understanding their day-to-day world in terms of a larger cosmic history, they tended to conceptualize these changes as a conflict between opposing cosmic forces that ultimately resulted in the triumph of God's salvific plan over the machinations of wicked demons. This model remained the dominant one for a thousand years or more, down into the early modern period, and among certain groups remains strong even today.

Among historians and other intellectuals, however, it began to give way to other models already in the 18th century. Many thinkers of that time adopted a stance that was, at least in practice, agnostic as regards the active intervention of superhuman forces in human affairs and the physical world and they consequently sought to explain phenomena without reference to them. One eventual result of this shift in thinking was the gradual conceptualization of 'religion' as a discrete and distinctive aspect of human society and culture, a phenomenon that could be analyzed purely in terms of social and cultural forces. The implicit model for this new concept of 'religion' was perhaps inevitably Christianity, Protestant Christianity in particular, but it was projected as a universal aspect of human culture, existing with some variation in all societies. Historians of the first few centuries after Christ who adopted this new intellectual framework accordingly reconceptualized the changes that took place in that period in terms of conflict or competition among different 'religions.' Probably the most famous example is Edward Gibbon, who analyzed historical developments in the first few centuries CE as the victory of one religion over others; for him, it was the job of the historian to identify the particular causes of that victory. ${ }^{3}$ For all Gibbon's carefully calibrated secularism, however, it is noteworthy that his analytical framework is in its essentials a modified version of the earlier confessional model of Christian triumph. Although he no longer interprets human historical developments as a byproduct of superhuman cosmic developments, he retains the underlying model of conflict and victory; it has simply become a conflict between different religions rather than different cosmic forces and the victory

2 My project obviously invites comparison with Guy Stroumsa's thoughtful but impressionistic essay (Stroumsa 2005). Despite its title, however, animal sacrifice is the focus of only one chapter in that wide-ranging work. Moreover, Stroumsa's interests lie chiefly in tracing the 'interiorization' of religion, whereas I am much more concerned with the ways that socio-political structures and relationships of power shape the discourse of 'religion.'

3 See Chapter 15 of the first volume of The Decline and Fall of the Roman Empire (1776), where Gibbon identifies five causes for the victory of Christianity: 'the inflexible and ... intolerant zeal of the Christians,' 'the doctrine of a future life,' the miracles attributed to early Christians, their 'pure and austere morals,' and 'the union and discipline of the Christian republic.' 
of one religion over others rather than that of God over demons. This 'conflict of religions' model remained the dominant scholarly model well into the 20th century. ${ }^{4}$

Over the course of the 20th century, however, a number of scholars developed new ways of modeling religious change in the Roman imperial period by analyzing developments not so much as a conflict between competing religions but rather as a transformation in the nature of religion itself. One could argue that there are moves in this direction even in the work of Cumont but the book that to me signals the start of a new approach is A. D. Nock's Conversion (Nock 1933), which he quite aptly subtitled 'The Old and the New in Religion from Alexander the Great to Augustine of Hippo.' Nock's chief contribution lay not so much in sketching the history of conversion but in offering the fundamental insight that the possibility of conversion was in itself evidence for a shift in the nature of religion. Although Nock himself was too beholden to an implicitly Protestant conception of religion to work out the implications of his insight as fully as we might now like, he pointed the way to new and more fruitful ways of modeling religious change in the Roman empire (Rives 2011b). Further impetus for developing this approach has come from outside the study of Mediterranean antiquity. Large-scale political and intellectual developments over the course of the last century have led an increasing number of scholars to call into question the universalizing notion of 'religion' that historians from Gibbon to Nock took for granted and these scholars have done much work to expose its underlying cultural bias and ideological presuppositions. ${ }^{5}$ Not surprisingly, the increasing awareness of the problems involved in using 'religion' as an unexamined analytical category has had a significant impact on the study of religious change in the Roman empire. Although a good deal of research continues to take place within the model of 'religious competition,' current scholars are by and large more self-conscious and cautious in using 'religion' as a simple analytical category and are more aware of the question-begging to which it can so easily lead. More and more are coming to agree, in various ways, with Jörg Rüpke's assertion that 'the most crucial development that occurred during the Roman Imperial Age was not a change or increase in the number of religions but a change in the phenomenon of "religion" itself and its status in society' (Rüpke 2014, pp. 1-2). As I see it, the challenge in studying religion in the Roman imperial period is to model a development that involved both a considerable continuity in cultural practices and beliefs and simultaneously a fundamental change in the conceptual framework within which contemporary actors understood those practices and beliefs. ${ }^{6}$

\section{Orthopraxy and Orthodoxy}

My own attempt to model religious change in the Roman empire is built around a contrast between orthopraxy and orthodoxy. ${ }^{7}$ My starting point is the now-clichéd view of the Graeco-Roman tradition of dealing with the gods as one focused on practice and Christian tradition as one focused on belief. Although this view was polemical in origin and led to unhelpful characterizations of Roman religion in particular as spiritually arid, scholars starting in the 1970s effectively managed to turn it on its head and characterize such dismissals of practice as implicitly Christianizing. ${ }^{8}$ Yet the great

4 See notably The Conflict of Religions in the Early Roman Empire (Glover 1909), which proclaims the model in its title, although a similar model informs a number of other influential books from that time, including Franz Cumont's Les religions orientales dans le paganisme romain, first published in 1909; see now the republication of the 4th edition of 1929 with a valuable historiographical introduction by Corinne Bonnet and Françoise Van Haeperen (Cumont 2006).

5 The monographs of Brent Nongbri (Nongbri 2013) and of Carlin Barton and Daniel Boyarin (Barton and Boyarin 2016) helped put this debate at the center of the study of ancient Mediterranean religion. For a cogent critique of Nongbri's argument, see the review by David Frankfurter (Frankfurter 2015).

6 I attempted to tackle a similar problem in tracing the development of a concept of 'magic' in the particular context of Roman legal discourse (Rives 2003).

7 It will be obvious that there is little in this model that is original to me. Although it would be impossible to document all my intellectual debts, I have tried to cite some of the most salient. Here I will mention only the elegant paper of Stanley Stowers, which I was fortunate to hear in person (Stowers 2011c).

8 Two of the key figures are Simon Price (especially Price 1984, pp. 1-22) and John Scheid (e.g., Linder and Scheid 1993). See also the contributions of John North (North 2000, pp. 76-85, especially North) and Clifford Ando (Ando 2003, pp. 1-15, especially Ando; reprinted in Ando 2008, pp. 1-18, at Ando.) 
advantage of this contrast between practice and belief, it seems to me, is that it helps us to move beyond characterizing these different traditions in terms of their conceptual content, an approach that already takes for granted the primacy of belief, and to think instead in terms of social structures and cultural practices. At the same time, more recent scholars, especially those with an interest in cognitive theory, have cogently demonstrated that a simplistic dichotomy between practice and belief is deeply problematic. Practice and belief are in fact two sides of the same coin: all practice necessarily presupposes belief and belief is in all cases both communicated by and more importantly shaped by practice. ${ }^{9}$

It thus seems to me more helpful to think of the relative prominence of practice or belief within a particular tradition not as some sort of innate quality but rather as a specific result of the exercise of social power. ${ }^{10}$ In terms of interacting with superhuman forces, are those who wield power and authority within a community more concerned with what people do or with what they think? I describe the former as orthopraxy, the use of social power to promote conformity to certain normative types of behavior. The latter I describe as orthodoxy, in which those with social power bring it to bear on people's beliefs. The ends to which social power is directed, it seems to me, is the fundamental issue that determines many other characteristics of these two modes of dealing with the divine. Orthopraxy tends inherently to be more fluid and open-ended: in terms of social context, it allows for multiple sources of religious authority; in terms of individual self-understanding, it allows for multiple non-conflicting identities and commitments. Orthodoxy, in contrast, tends inherently towards what I have elsewhere characterized as exclusivity, homogeneity and totalization (Rives 2005; see also Rives 2011b). It is of course not really possible to bring social power to bear on beliefs directly: some type of communication, normally verbal communication, is needed in order for authorities to monitor and shape them. I would accordingly propose that a more precise way of characterizing orthopraxy and orthodoxy is in terms of communicative strategies: do authorities privilege cult practices as the primary form of communicating ideas about the divine or do they privilege verbal discourse?

One final proviso before I present my model in more detail. I have so far been assuming that social power is prior to modes of dealing with the superhuman sphere and that it hence can define and shape what we could describe as 'religion' within a given society. That is true enough in some cases and to some extent. But social power can itself be constituted by particular modes of conceptualizing the divine. That is, the claim to have some sort of privileged connection with or access to the superhuman sphere, along with the widespread acceptance of that claim, can in itself endow particular individuals or groups with a degree of social power. In the case of Christianity, the working out of orthodoxy as a new form of religion was inextricably interwoven with the development of forms of authority within the Christian community. As I will suggest below, the need of would-be Christian leaders to establish their social authority was one of the driving forces that shaped the early Christian tradition as one of orthodoxy.

\section{Animal Sacrifice and Orthopraxy in the Graeco-Roman Tradition}

I begin with orthopraxy, which I have characterized as the privileging by social authorities of cult practices over verbal discourse as the primary medium of communication in matters connected with the divine. While it is a truism that the Greek and Roman traditions lacked scripture, we should be clear that this is not the same as saying that texts had no significant role to play. Texts in fact played an immensely important role in the Graeco-Roman world in delineating the nature of the gods and in

9 A number of scholars have in various ways emphasized the importance of belief in Roman religion (e.g., Feeney 1998, pp. 12-46; King 2003; Mackey 2009). Harvey Whitehouse offers a sophisticated cognitive model (Whitehouse 2004); what I refer to here as 'practice' corresponds roughly to Whitehouse's 'cognitively optimal 'mode.

10 My interest in the role of social power in shaping the structure of religious traditions goes back to a paper of Talal Asad (Asad 1983; revised as Asad 1993). Although this essay strikes me as less cogent now than it did when I first read it over thirty years ago, I must acknowledge the influence it had on my thinking about these issues. 
shaping human interactions with them. They did this in a wide variety of ways: by enumerating and describing the powers and attributes of individual gods, by relating narratives about their actions and deeds, by speculating about their ultimate nature, by examining their intervention in human affairs, by describing and codifying the cult practices that were intended to win their goodwill, by making public declarations of particular instances of devotion, by recording tactics for accessing their power in ways not available to the multitude and by offering privileged access to their superhuman wisdom and knowledge. We may recognize here the roles played by different literary genres: hymns, epic, tragedy, philosophy, history, antiquarianism, cultic regulations, votive dedications and various types of esoterica, to name only the most obvious. Yet very few of these texts were produced or in any direct way sponsored by socio-political authorities. They might well endow their authors or interpreters with a measure of social power and as a result established authorities might attempt to co-opt or restrict them but there was no systematic relationship between these kinds of texts and socio-political authorities. The texts that were actually issued by political authorities tended to be much more limited in scope and typically consisted of pronouncements about the status of certain individuals or structures (the dedication of public shrines, for example) or guidelines for particular types of actions. These were sometimes negative, such as the Senatus Consultum de Bacchanalibus that restricted the worship of Dionysus in Italy in the 2nd century BCE, but were much more often positive, as with the various regulations that are conventionally if awkwardly classed as leges sacrae. Even the edicts of the emperors Decius and Valerian, which we think of as having the negative goal of persecuting Christians, seem in fact to have been framed in positive terms of requiring people to perform particular types of cult actions (Rives 2011a, pp. 211-13). Socio-political authorities in the Graeco-Roman world thus tended to treat texts primarily as tools for regulating practice and accordingly as subordinate to practice. In other words, they used texts to reinforce practice as the privileged form of communication with respect to the divine world.

So what did this practice communicate and how did it do so? I will address these questions by examining a particular type of practice, animal sacrifice. ${ }^{11}$ It has for a number of years been a commonplace to describe animal sacrifice as the most central cult act of the Greek and Roman traditions. I believe this to be true, at least to some extent, but not because it was the most common cult practice, which it was certainly not, nor because contemporaries regarded it as the one cult practice indispensable for maintaining the goodwill of the gods, which likewise they certainly did not, but rather because the social, economic and political elites of the Graeco-Roman world bestowed upon it a privileged cultural position. They did so not by means of regulation and enforcement, which prior to the mid-third century CE was infrequent and unsystematic, but instead by endowing with a certain glamour. This much is readily apparent from extant art and literature and from what we can reconstruct of public cult practice. More of what I mean by 'glamour,' which is perhaps not a word most people would associate with animal sacrifice, should emerge as I turn to the question of what it was that animal sacrifice communicated.

Most obviously, animal sacrifice communicated some basic beliefs about the nature of the world and about the role of humans within it: the belief that there are superhuman beings, that these beings have power to help or harm humans, that humans must accordingly take actions to ensure that these beings use their power to help and not harm them and that they have responses similar to those of humans, for example, that they respond favorably to gifts and demonstrations of respect but can take umbrage if they are neglected or slighted. People who had a particular interest in such matters debated the details of these beliefs, for example, the efficacy of animal sacrifice and the reasons for it, and at times even rejected some of them altogether, as for example the Epicureans did, who insisted that the gods had no interest whatsoever in human affairs. We can find traces of these debates most obviously in various philosophical and poetic texts, which suggests that they had fairly wide circulation, at least

11 There is now a vast bibliography on this topic (Ullucci 2015; Naiden and Rives 2016). 
among certain classes. With rare exceptions, however, socio-political authorities showed little concern for these debates. Their concern was instead, as I have already suggested, solely with the practice itself and not with what people thought about it. Lastly and again with a few exceptions, they were not even concerned with ensuring that everyone engage in practices such as animal sacrifice on an individual basis; it was enough that favored practices had a central role in the public sphere. The promulgation of particular beliefs about the divine, in short, especially on an individual basis, was clearly not the primary reason why socio-political elites promoted animal sacrifice as a privileged cult practice.

Why, then, did they promote animal sacrifice? As I have already noted, animal sacrifice was by no means the only or even the most important form of offering, at least from what we might call a theological point of view. Fred Naiden has cogently demonstrated that the ancient Greeks did not single out animal sacrifice from other types of offerings as being in some way more efficacious in winning divine goodwill (Naiden 2013) and in a recent article Celia Schultz has made a similar point with regards to the ancient Romans (Schultz 2016). What did distinguish animal sacrifice from other forms of offerings were two things that had relatively little to do with beliefs about the gods. First, animal sacrifice was on average more expensive than other types of offerings. I say 'on average' because there was a huge range in the cost of animal sacrifices, extending from piglets and lambs at one end to full-grown bulls at the other. By and large, however, animals were valuable resources that most people could not afford to consume on anything like a regular basis. There were of course other kinds of offerings that could be even more costly: monumental altars and temples, dedications made of expensive materials, elaborate spectacles. But animal sacrifice, and this is its second distinctive feature, was the only form of offering that produced a highly desirable consumer good, high-grade edible meat. Although this meat could be consumed in very different ways (eaten on the spot by a larger or smaller number of participants, distributed for later use to a larger or smaller number of recipients, sold for resale in markets), the connection between the money needed to purchase the sacrificial victims and the meat that derived from them was, it seems, always acknowledged.

As a practice intended to establish good relations with the divine, then, what was truly distinctive about animal sacrifice was that it constituted an opportunity for the wealthy to enact their superior social status. Only they had the resources to offer animal sacrifice on a regular basis and to observe the various ritual requirements that so often hedged the selection of victims. Just as it was wealth that gave people the right to take a leading role in civic affairs, so too through the practice of animal sacrifice wealth gave them a privileged role in maintaining relations with the gods and allowed them to place others in the role of dependents or subordinates. In this way animal sacrifice, more than any other type of offering, helped structure the socio-economic and political hierarchies that were fundamental to the smooth functioning of the Roman empire, what Richard Gordon termed 'the civic compromise' (Gordon 1990). ${ }^{12}$ In this connection it is worth noting that the implicit beliefs about the divine that animal sacrifice communicated can to some extent be understood as a projection onto the divine level of the sort of unequal social relationships that animal sacrifice helped structure on the human level.

At the same time as animal sacrifice communicated a particular type of socio-political structure, it also communicated a particular type of cultural identity, which for lack of a better term we may describe as 'Graeco-Roman' identity. Although our ways of talking about cultural and ethnic identity in the Graeco-Roman world are currently under intense scrutiny, I think that it would not be too controversial to assert that there was a set of cultural practices and behaviors, somewhat loosely defined but not too fluid, that was shared by local elites throughout the Roman world and that to some extent served to link them both with each other and with the imperial center. Animal sacrifice was one of those practices and arguably one of the more important. First, as I have just suggested, it helped structure the socio-political hierarchies that Roman authorities cultivated as a crucial element

12 I have elsewhere analyzed at greater length the role that animal sacrifice played in structuring the socio-political hierarchies of the Roman world (Rives). 
in their system of rule. Second, the fact that it was native to both the Greek and the Italo-Roman traditions meant that elites in both traditions could regard it as natural and universal in a way that many other practices, more clearly marked as either Greek or Roman in origin, could not. Third, animal sacrifice was closely associated with what was perhaps the supreme and unique unifying element of the Roman world, the figure of the emperor. The emperor was both represented as the ideal sacrificant and was himself made the object of animal sacrifice (Rives). For all these reasons, then, animal sacrifice functioned as a distinctively Graeco-Roman practice and to participate in it was to enact one's social and cultural identity as a certain type of participant in the Roman empire.

Having analyzed what the practice of animal sacrifice communicated, we may now consider how it communicated. The 'how' of orthopraxy is a crucial part of my analysis, because in my view it was the mechanics, even more than the content, that determined its most distinctive characteristics. I have already hinted at how animal sacrifice communicated its meanings: it did so not by presenting them discursively but by modeling them, by (in a very literal sense) embodying them. To apply a famous catchphrase from Marshall McLuhan, the medium was the message (McLuhan 1964, Chp. 1): the social and economic relationships performed in the act of animal sacrifice were the specific meaning that it served to communicate, the meaning that distinguished it from other types of actions and offerings meant to please the gods. Or to use the semiotic terminology of C. S. Peirce, animal sacrifice was an index, "a sign which is fit to serve as such by virtue of being in a real reaction with its object" (Peirce 1998, p. 306); what it signified was the particular type of socio-economic structure in which it took place. ${ }^{13}$ Throughout the Graeco-Roman world, it was by means of participation in animal sacrifice, whether actively as performers or passively as observers or even as the indirect recipients of the meat, that people absorbed (so to speak) the social and cultural information that it encoded.

This mode of communication left room for a great deal of interpretive leeway on the part of individual participants. People could engage with the practice within a wide variety of conceptual frameworks and in combination with a wide range of other cultural or ethnic commitments. As I have already noted, socio-political authorities were by and large not concerned with these other frameworks and commitments, because they were in a very real sense extraneous to the meaning of animal sacrifice with which they were concerned, that is, its modeling of the socio-political structures and cultural allegiances in which they were invested. It was for this reason that the Graeco-Roman tradition of orthopraxy allowed so much space for multiple sources of authority and multiple overlapping social identities.

\section{Animal Sacrifice and Orthodoxy in the Early Christian Tradition}

In contrast to the Graeco-Roman tradition, those who aspired to and assumed positions of leadership within the developing Christian tradition seem to have regularly privileged verbal discourse over practice as the primary form of communication. This is not to say that they were unconcerned with practice; on the contrary, the issue of how Christ-followers are to behave is a constant focus of interest in our extant evidence. But whereas socio-political authorities in the Graeco-Roman tradition subordinated text to practice, early Christian leaders generally subordinated practice to text. Instead of using text to describe, enact and regulate practice, they used it to articulate the beliefs that justified and explained the practice, so that practice appeared to be determined by and dependent upon these verbally articulated beliefs. This privileging of verbal discourse as the primary mode for the communication of beliefs, I argue, played an important part in shaping the Christian tradition as one of orthodoxy and in fueling its distinctive drive towards exclusivity, homogeneity and totalization. Just as

13 The essay quoted was first written in 1904. Peirce continues: "For example, a weathercock is such a sign. It is fit to be taken as an index of the wind for the reason that it is physically connected with the wind. A weathercock conveys information; but this it does because in facing the very quarter from which the wind blows, it resembles the wind in this respect." Much the same could be said, mutatis mutandis, of animal sacrifice and the socio-economic structure of the Graeco-Roman world. For further discussion and examples of indexes, see his earlier essay in the same volume (Peirce 1998, pp. 13-16). 
I chose the specific practice of animal sacrifice to explicate my notion of orthopraxy, I here focus on a specific example of verbal discourse, Paul's discussion of sacrifice in his first letter to the Corinthians.

An important preliminary point concerns Paul himself. Although it is commonplace to describe Paul as a Christian, it is very doubtful whether Paul would have thought of himself in this way. The origins of the term 'Christian' are much debated but there is no evidence that Paul ever applied it to himself. Paul did, however, identify himself very firmly as a Judaean, ${ }^{14}$ and we should consequently locate his letters in the wider context of Judaean strategies for shaping and transmitting their tradition in the years prior to the mid-1st century CE. One of the most striking features of these strategies is the extent to which they prioritize verbal discourse. This impression is no doubt due in part to the nature of our evidence. We have very little access to the transmission of Judaean ancestral traditions through everyday practice, even though there is good reason to think that this was a pervasive phenomenon; what we have instead are texts. ${ }^{15}$ Yet the central role played by verbal discourse is not, I believe, merely an illusion generated by the particularities of our evidence. The use of texts as a primary medium for transmitting and shaping beliefs about the relationship between the Judaean people and their god apparently extends back into the early first millennium BCE. It is important to note that Judaeans employed texts both to transmit and also to shape their tradition. Over the course of the Second Temple period there is abundant evidence for a wide range of discursive strategies for manipulating the scriptural tradition in order to persuade people to adopt new practices and beliefs under the guise of something old: the production of new texts attributed to figures known from older texts, the interpretation or outright rewriting of older texts to apply to new situations and debates over the precise application of injunctions found in older texts. ${ }^{16}$ Those debates and discussions dealt with practice as often or even more often than they did with belief but the very fact that they took the form of verbal discourse is what I would like to stress here. It is within this larger context that we should locate the letters of Paul.

Turning to 1st Corinthians, we may first of all note that it exemplifies the early Christian concern with practice. The passage on which I am focusing is that which concerns eidolothuton, a previously unattested Greek word that means literally something like 'idol-sacrifice' but which, as the context suggests, Paul uses to denote meat from animals that have been sacrificed to gentile gods (8:1-11:1). ${ }^{17}$ He is apparently responding to an inquiry posed by some of his Corinthian associates. Paul's writing in this passage is, as so often, highly elliptical and allusive, so that there is considerable disagreement about the precise structure of his argument (Fitzmyer 2008, pp. 330-404, especially 332). I offer the

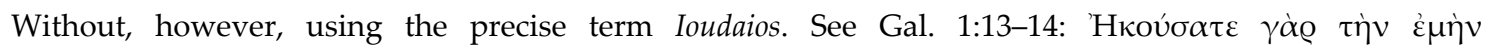

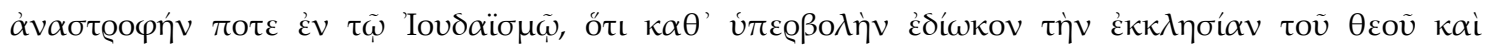

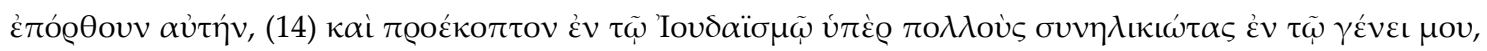

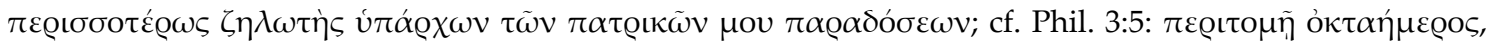

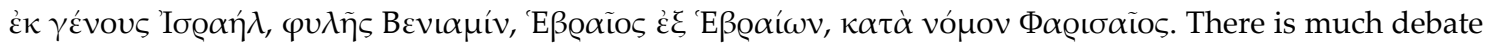
whether the Greek term Ioudaios is better translated as 'Judaean' or 'Jew'; see the forum published in Marginalia: Review of Books on 26 August 2014 at http:/ / marginalia.lareviewofbooks.org/jew-judean-forum/. I have here adopted 'Judaean' partly because of its ethnic connotations and partly because of its distancing effect, without any intent to erase Jews from antiquity.

15 To the extent to which we can access the transmission of Judaean tradition through practice, we must infer it from archaeological evidence, perhaps supplemented by stray remarks in literary sources (e.g., Berlin 2005).

16 Pseudepigrapha: e.g., the texts brought together in 1 Enoch, as well as the Testaments of the Twelve Patriarchs, the Testament of Moses, the Wisdom of Solomon and Baruch. Interpretations: e.g., the fragmentary commentaries on the prophets found at Qumran (4Q161-9), especially that on Habakkuk (4QpHab). Rewriting: e.g., 1 and 2 Chronicles, Jubilees. Debates: the combined evidence of the Gospels and the Mishnah suggest that debates over the interpretation and application of the law extend back at least to the late Second Temple period.

17 The only other extant example of the word that is contemporary with Paul is at 4 Macc 5:2, although it later appears in other early Christian texts (Acts 15:29 and 21:25, Rev. 2:14 and 20, Didache 6:3). 
following analysis merely as an illustration of his approach, not as a substantive contribution to the interpretation of this difficult passage. ${ }^{18}$

Paul begins by addressing the topic of 'understanding,' gnosis, within which his interlocutors had apparently framed their inquiry. His handling of this topic involves three stages. First, he establishes a contrast between gnosis and agape, 'love' (8:1-3). He then moves on to address the specific content of the gnosis in question, the ontological status of idols (8:4-5). Rather than resolving that issue, he caps it with the assertion that "for us there is one God, the Father, from whom are all things and for whom we exist, and one Lord, Jesus Christ, through whom are all things and through whom we exist" (8:6), which many scholars have interpreted as a pre-formulated statement of belief that Paul had received from others (Fitzmyer 2008, pp. 336-37). Lastly, he advances an argument that depends on a contrast between those who have gnosis and are free and those who lack gnosis, two groups that he also characterizes as the strong and the weak (8:7-9): if the latter see the former taking a meal in the shrine of an idol, he says, they may be encouraged to eat idol-food and be destroyed and so it is better to abstain altogether (8:10-13).

At this point Paul seems to shift subjects entirely, in the apparently stream-of-consciousness drift that is so characteristic of his style, and moves into a long passage in which he discusses his own credentials and actions (9:1-27). Although its connection with what precedes is oblique, it seems to turn on the notion that Paul, like his addressees, has the freedom and power to do certain things and enjoy certain benefits but chooses not to do so out of a concern for the people to whom he is bringing his message (cf. 8:13); although he does not use the actual terms here, his argument evokes the contrast between gnosis and agape that he has previously established.

He then appears to switch subjects again and employs a series of highly figurative allusions to stories of the Israelites in the wilderness in order to urge his audience not to make the same mistakes that they did (10:1-13). He eventually reveals his point in referring to these stories in an emphatic exhortation: "Therefore, my dear friends, flee from the worship of idols" (10:14). Without saying so explicitly, he next makes it clear through a three-stage metaphorical modulation that eating food sacrificed to idols is tantamount to idolatry. The first stage introduces the Christian practice of sharing wine and bread, which he equates with sharing the blood and body of Christ (10:16-17); this is a practice whose conduct and significance he will discuss in more detail a bit later in the letter (11:17-34). The second move, which invokes the Judaean sacrificial tradition that he has twice invoked earlier in the letter $(5: 7 ; 9: 13)$, establishes an analogy between Christ-followers who share bread and wine with Judaeans who share the meat from a sacrifice (10:18). He prefaces the third and last move by circling back to the gnosis that idols have no real existence and then, in a rhetorically effective if logically elusive shift, asserts that "what pagans sacrifice, they sacrifice to demons and not to God. I do not want you to be partners with demons. You cannot drink the cup of the Lord and the cup of demons. You cannot partake of the table of the Lord and the table of demons" (10:21-22).

Yet this resounding dictum is not the end of his response. He returns to the starting points of his discussion, the contrast between actions that are lawful for believers with gnosis and actions that are beneficial to their fellows (10:23-24), and then proceeds to lay down some further guidelines about eating: Christ-followers may eat meat from the market or dine with unbelievers without inquiring into the origins of the food they are consuming (10:25-27). Although at first sight these guidelines appear to be at odds with the emphatic pronouncement that immediately precedes them, commentators have persuasively argued that the absolute prohibition applies when one is certain that the food in question comes from offerings to idols but that in uncertain cases one is not obligated to make that determination. Paul's next statement seems to confirm this interpretation: "But if someone says to you, 'This has been offered in sacrifice,' then do not eat it, out of consideration for the one who informed you

18 I owe thanks to William H. Race for his insightful comments on Paul's rhetorical strategies in this passage. All quotations are from the New Revised Standard Version, except where noted otherwise. 
and for the sake of conscience-I mean the other's conscience, not your own" (10:28-29). In relation to the present discussion, we might say that what one believes about the food is the crucial matter, not the food itself. ${ }^{19}$ Paul concludes his discussion by once more holding up his own behavior as an example: one should always seek the advantage of others, not oneself (10:33-11:1).

In Paul's discussion of animal sacrifice, then, the medium is again the message. Although it is the physical act of eating food sacrificed to idols that is in question, Paul firmly subordinates that physical act to the elaborately articulated verbal discourse within which he frames his response, in such a way that the meaning and significance of the act become dependent on the verbal discourse. What matters, ultimately, becomes the articulation of a set of beliefs that inform the meaning of practices and consequently determine their acceptability and appropriateness.

The emphasis on verbal discourse and the articulation of beliefs that we find in this passage of 1 st Corinthians and in Paul's letters more generally results in part from the particular social circumstances within which he was operating. The structures of social power in the Graeco-Roman world were long established and although they were subject to constant negotiation and renegotiation we may reasonably identify as one of the fundamental constants the principle that wealth translated to social prestige and political power. That is to say, the socio-political leaders of the Graeco-Roman world were in a position to exercise their authority without needing to establish it first. In striking contrast, communities of Christ-followers in Paul's day were in the process of inventing themselves and those who wished to assume leadership roles within these nascent communities effectively had to create them. There was a range of devices that people could employ to claim authority for themselves. Wealth and social status no doubt played an important part, just as it did in the Graeco-Roman world more widely, and already in the time of Paul it seems that those whose homes were large enough to accommodate assemblies of believers had ipso facto a certain standing in their community. ${ }^{20}$ Proximity to the historical Jesus must also have been important in the earliest decades, although this was not a source of authority that Paul himself could claim. He instead tended to ground his authority in his claims of having had a direct encounter with the living, divine Christ, who directly commissioned him to proclaim his message..$^{21}$ Yet perhaps the most important tactic of all was persuasion. ${ }^{22}$

The letters of Paul, and 1st Corinthians is certainly no exception, are nothing if not bravura displays of persuasive self-presentation, as Paul seeks first and foremost to establish his own authority. ${ }^{23}$ Throughout the letter he displays a brilliant command of a wide range of rhetorical techniques, something that should be apparent even from my summary analysis of this one passage: he relies heavily on question, antithesis and above all metaphor to generate and convey his meaning. ${ }^{24}$ Another key item in Paul's tool kit of persuasion, to which I have already alluded, is his claim to have access to superhuman wisdom. At the start of the letter he emphasizes that his knowledge and understanding are not of human origin but have a divine source: "we speak of these things in words not taught by human wisdom but taught by the Spirit, interpreting spiritual things to those who are spiritual" (2:13). Although there are many other strategies that could be discussed, the last that I will mention here his command of Judaean scripture. I have already noted the central role of scripture and verbal discourse in the Judaean tradition in which Paul was so steeped. Paul's audience, however, consisted not of Judaeans but rather of non-Judaeans, some of whom may well have known nothing

19 I am grateful to Janet Spittler for calling my attention to the particular relevance of this passage for my argument.

20 Examples of such people in 1st Corinthians would include Chloe, whose people brought Paul reports of the goings-on in Corinth (1:11); Stephanas, whose household he baptized (1:16 and 16:17); and Aquila and Prisca, whose house in another city serves as the meeting place of an assembly (16:19).

21 See especially 1 Cor. 9:1 and 16-18 and 15:1-11. Paul's consistent self-designation as a messenger (' $\alpha \pi$ ó $\sigma \tau \mathrm{\tau} \lambda$ oo) is in itself an assertion of the charismatic basis of his authority; see 1:1, 1:17, 4:9.

22 I am grateful to Bruce Lincoln for his insistence on this point.

23 I do not mean to imply that Paul's primary concern was with his own power and social standing but rather that, in order to convey his message, he first had to give people a reason to listen to him and take his message seriously.

24 Kennedy (1984, pp. 141-56) provides a pioneering study of Paul's mastery of rhetorical techniques. Patterson (2015) offers a rich exploration of one interconnected set of key metaphors in 1st Corinthians, those connected with sacrifice. 
at all about the Judaean scriptures prior to their encounter with Paul and other Christ-followers. For such people the persuasive power of Paul's deployment of these writings lay not in their traditional authority but rather in their novelty and exoticism, in the perception of them as exemplars of ancient and alien wisdom. ${ }^{25}$ The reason that Paul appeals so frequently to the sacred writings of the Judaeans in writing to people who may have known relatively little about them is that his authority was to a large extent grounded in his apparent mastery of this exotic and compelling lore. ${ }^{26}$ Although he does not explicitly quote from scripture in his discussion of food offered to idols, we have seen that he grounds his injunction against idolatry in a figurative exegesis of the account of the Israelites' journey through the wilderness, whose significance for his audience he has the ability to reveal: "These things happened to them to serve as an example, and they were written down to instruct us, on whom the ends of the ages have come" (10:11). Paul thus employs a range of persuasive tactics to establish his own authority vis-à-vis his audience.

Paul's reliance on the tactics of persuasive self-presentation is one of the things that leads him to prioritize belief over practice. Although he lacks the power to regulate the practices of his Corinthian audience, he does have the ability to persuade them to accept his understanding of the cosmos, which, if successful, would result in their own self-regulation. As we have seen, the whole debate over eating food sacrificed to idols hinges on correct understanding. Some Corinthians apparently held that their special knowledge that idols are nothing meant that eating food offered in sacrifice to gentile gods had no significance for them as Christ-followers. Paul, without firmly agreeing or disagreeing with their understanding of idols, argues that something more was at stake, that Christ-followers who believe that idols are in fact something could be drawn away from Christ and into association with demons by eating food that had been sacrificed to them. In a complex way, then, belief seems to have absolutely central to Paul's debate with his Corinthian interlocutors over idol-sacrifice. ${ }^{27}$

In arguing that Paul prioritizes belief over practice, however, I do not mean to suggest that his goal was the articulation of formalized doctrines. As we have already seen, Paul relies much more on rhetorical, even poetic, strategies than on the sort of logically precise analysis that we regard as typical of Classical and Hellenistic Greek philosophy. It is for this reason that some contemporary scholars prefer to refer to Paul's activity as "mythmaking" rather than the formulation of doctrine (e.g., Stowers 2011a). ${ }^{28}$ Nevertheless, as Stanley Stowers has convincingly demonstrated, Paul's mythmaking was in a number of fundamental respects more similar to Hellenistic philosophy than it was to traditional Graeco-Roman cult practice. Stowers points out that "the central practices of the Hellenistic schools and of Pauline Christianity were intellectual practices and practices that made reference to mind." Likewise, "both were centrally concerned with the reading, writing, transmission and interpretation of texts" and with "teaching, learning and moral training" (Stowers 2011b, p. 234). ${ }^{29}$

25 Thus Stanley Stowers (2011a, p. 123) argues that "the central vehicle for much of his mythmaking is Paul's interpretation of Judean scripture. His access to books, ability to read and write proficiently and exegetical practices gave him intellectual skills that few, if any, of the Corinthians are likely to have had." Heidi Wendt provides a compelling analysis of Paul as a freelance religious expert Wendt (2016, pp. 146-89, especially Wendt on his self-presentation as an exegete of Judaean scripture).

26 For explicit citations prefaced by a phrase like 'as it is written,' see 1 Cor. 1:31 (Jer. 9:24), 2:9 (Is. 64:4 and 52:15), 3:19 (Job 5:13), 3:20 (Ps. 94:11), 9:9 (Dt. 25:4), 14:21 (Is. 28:11-12; cf. Dt. 28:49), 15:45 (Gen. 2:7) and 15:54 (Is. 25:8) and 55 (Hos. 13:14). Other quotations are not explicitly signaled as such, e.g., 2:16 (Is. 40:13), 5:13 (Dt. 17:7, 19:19, 22:21 and 24, 24:7), 6:16 (Gen. 2:24) and 15:32 (Is. 22:13 and 56:12).

27 Peter Tomson (1990, pp. 151-220) provides a rich study of the way that Paul's argument here compares to later rabbinic halakha. Just as the rabbis of the Mishnah located idolatry not "in the nature of things themselves but in the way people treated them" (p. 159), so too Paul is concerned above all with the consciousness of the food's use in an idolatrous context. For Paul, idolatry exists not in the object but in the participant's own understanding of what he or she is doing: "The reality of idolatry is not in food but in people's minds" (p. 219).

28 We should, however, keep in mind that mythmaking of this sort is by no means alien to the Greek philosophical tradition: in various ways it plays a significant part in the work of Plato and is a dominant mode in the Pythagorean tradition that in the time of Paul was undergoing a revival.

29 Stowers continues with an instructive comparison of the major rituals of Pauline Christianity with Graeco-Roman sacrificial ritual. Although prayer was a fundamental element of the latter, it involved no teaching, no narrative, no "interpretation of the soul of or texts." In contrast, "in the Lord's supper according to 1 Cor 11, the meal recalls a foundational myth of the group and certain words and actions in the ritual make reference to that story. Participants are to examine their motivations 
Stowers concludes that "Paul's groups were constituted by social formations that 'exalted' discursive practices over non-discursive practices and that tended to treat non-discursive practices and affects as valuable to the extent that agents could attribute discursiveness to them" (Stowers 2011b, p. 241).

The two features of Pauline strategizing that I have identified, the reliance on verbal discourse as a tool for establishing his authority and the prioritizing of beliefs over practice, reinforced one another in a self-perpetuating dynamic. On the one hand, as long as there was a need for Christian leaders to establish or shore up their positions of authority, there was a tendency for them to have recourse to much the same tool kit of persuasion that we find in the letters of Paul and thus to privilege verbal discourse as a tool for the articulation of belief. On the other hand, the prioritizing of beliefs tended to perpetuate an emphasis on techniques of persuasion and a privileging of verbal discourse, because verbal discourse provides a much more effective and precise tool for the articulation of belief than does practice, which tends instead to allow for open-ended and multiple sets of beliefs. As a result of this self-reinforcing dynamic, the formulation and reformulation of beliefs became a constant and on-going aspect of the development of Christianity.

In this context, the precision afforded by verbal discourse inevitably had liabilities as well as advantages, since it made inconsistencies and disagreements much more readily apparent. The stress on belief, in turn, created pressures to determine which beliefs were the right ones, which quickly led to fierce claims and counter-claims. 1st Corinthians provides vivid evidence that just a few decades after the death of Jesus there were already significant disagreements over matters of belief and practice among people who seem in one way or another to have regarded themselves as Christ-followers. Paul's response to this situation was to affirm a goal that in ensuing centuries would become as insistent as it was elusive: "I entreat you, brothers, by the name of our lord Jesus Christ, that you all say the same thing and that there not be divisions among you and that you be fully prepared in the same mind and in the same understanding." ${ }^{\prime \prime 0}$ We see here in a nutshell the drive towards homogeneity that is one of the most distinctive characteristics of nascent Christianity and that we can trace from the ad hoc disputes alluded to in early Christian letters (the Johannine epistles, Jude, 1 Clement, Ignatius), through the crystallization of the discourse of heresy by Irenaeus in the late 2nd century and down to the ever more minute Trinitarian and Christological controversies of the 4th and 5th centuries.

Orthodoxy, then, is characterized by an emphasis on belief and on its articulation by means of verbal discourse. In early Christianity, the development of orthodoxy was tightly interwoven with the creation of positions of authority. For those who sought to establish themselves as community leaders, the articulation of beliefs and, more importantly, claims to the articulation of correct beliefs provided an important tool for establishing their authority. These claims and counter-claims resulted in the internal controversies that characterized early Christianity and the drive towards exclusivity, homogeneity and totalization that I have posited as a key characteristic of orthodoxy.

\section{Some Qualifications and Caveats}

In the case of both orthopraxy and orthodoxy, I would argue that the relationship between the nature and source of social power on the one hand and choice of communicative strategy on the other is what generates the defining characteristics of the two cultural patterns, the structures that in the one case allow for fluid and non-contradictory beliefs and multiple identities and that in the other case tend much more towards exclusivity and homogeneity. The story of religious change in the Roman empire

and attitudes toward the community in light of the story and of God's knowledge of their inner condition. Unlike the first ritual, the second requires speaking, interpretive, textual practices and an articulated technique of the self" (Stowers 2011b, pp. 234-35).

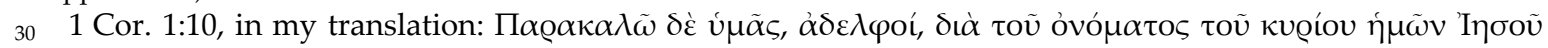

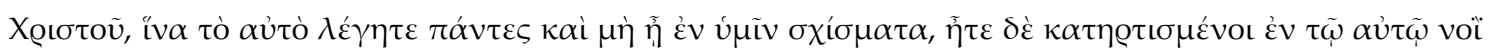

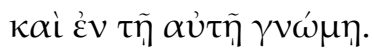


can thus to some extent usefully be described in terms of shifts and tensions between orthopraxy and orthodoxy.

In closing, however, I want to stress some of the limitations of the model that I present here. First and foremost is the fact that it is only a model. Neither orthopraxy nor orthodoxy exist in pure form. They are instead abstractions that streamline and simplify much messier and more complex cultural and historical processes. As such, they serve as a useful tool for charting some of the structural changes in Graeco-Roman society and culture that allowed for both a continuity in practices and beliefs and a change in the way that contemporaries conceptualized those practices and beliefs. Yet we must always remember, to use Jonathan Z. Smith's memorable formulation, that map is not territory (Smith [1978] 1993). We cannot reduce the Graeco-Roman tradition to orthopraxy, nor the early Christian tradition to orthodoxy. If orthopraxy was the dominant mode in the Graeco-Roman religious tradition, as I have tried to argue, that was due in part to the very fact that it was traditional and thus embedded in well-established structures of social power. At the same time, there is abundant evidence for individuals or groups in the Graeco-Roman world who tried to establish their authority vis-à-vis the divine world outside of or in addition to these traditional socio-economic hierarchies. Among these individuals and groups, philosophers, say, or the various figures that Heidi Wendt has categorized as freelance religious experts (Wendt 2016), we find a similar reliance on persuasion and the same privileging of verbal discourse that among Christ-followers eventually led to orthodoxy. Likewise, traditional structures of social power existed also among the earliest Christ-followers, so that in Christianity there were from the start tendencies towards orthopraxy. These tendencies only increased over the course of the first few centuries CE, as Christians developed their own structures of communal authority. The alliance of these institutionally-based Christian authorities with Roman imperial authorities that took place after the conversion of Constantine meant that by the 4th century Christian leaders, much like the Graeco-Roman civil authorities of previous centuries, had the social power to regulate practice by decree. One could indeed make a good case that the Christianity of late antiquity was as much a system of orthopraxy as orthodoxy, although I would argue that the latter remained the dominant idiom.

Second, as I indicated at the start, my model is essentially descriptive and does not in itself address complex issues of causality. Yet the articulation of precise descriptive terms is a crucial preliminary to any sort of more ambitious project, whether historical or comparative. In the larger project for which this is a preliminary study, I plan to examine more broadly and in more detail the role of animal sacrifice in relation to the driving forces behind the religious transformation of the Mediterranean world. Analysis of those forces must take place on two levels, the macro and the micro. On the one hand, we must take into account the effects of large-scale socio-economic and political tendencies. On the other, we need to remain aware of the agency of the individuals who exercised agency within those large-scale forces, as David Frankfurter has recently done so brilliantly in his study of the Christianization of Egypt (Frankfurter 2018). In an important sense, this essay is merely a preliminary study but one that I hope will contribute something to the wider discussion of animal sacrifice and the conceptual frameworks within which we understand it.

Funding: This research received no external funding.

Conflicts of Interest: The author declares no conflict of interest.

\section{References}

Ando, Clifford. 2003. Introduction: Religion, Law and Knowledge in Classical Rome. In Roman Religion. Edited by Clifford Ando. Edinburgh: Edinburgh University Press, pp. 1-15. ISBN 0-7486-1565-2.

Ando, Clifford. 2008. The Matter of the Gods: Religion and the Roman Empire. Berkeley: University of California Press, ISBN 978-0-520-25083-3.

Asad, Talal. 1983. Anthropological Conceptions of Religion: Reflections on Geertz. Man 48: 237-59. [CrossRef] 
Asad, Talal. 1993. The Construction of Religion as an Anthropological Category. In Genealogies of Religion: Discipline and Reasons of Power in Christianity and Islam. Baltimore: John Hopkins University Press, pp. 27-54. ISBN 0801846315.

Barton, Carlin A., and Daniel Boyarin. 2016. Imagine No Religion: How Modern Abstractions Hide Ancient Realities. New York: Fordham University Press, ISBN 9780823271191.

Berlin, Andrea. 2005. Jewish Life before the Revolt: The Archaeological Evidence. Journal for the Study of Judaism 36: 417-70. [CrossRef]

Cumont, Franz. 2006. Les Religions Orientales dans le Paganisme Romain. Reprint of the 4th ed. Edited by Corinne Bonnet and Françoise Van Haeperen. Turin: Nino Aragno.

Feeney, Denis. 1998. Literature and Religion at Rome: Cultures, Contexts and Beliefs. Cambridge: Cambridge University Press, ISBN 0-521-55104-8.

Fitzmyer, Joseph A. 2008. First Corinthians: A New Translation with Introduction and Commentary. The Anchor Yale Bible. New Haven: Yale University Press, ISBN 978-0300-14044-6.

Frankfurter, David. 2015. Review of Nongbri 2013. Journal of Early Christian Studies 23: 632-34. [CrossRef]

Frankfurter, David. 2018. Christianizing Egypt: Syncretism and Local Worlds in Late Antiquity. Princeton: Princeton University Press, ISBN 9780691176970.

Glover, Terrot Reaveley. 1909. The Conflict of Religions in the Early Roman Empire. London: Methuen \& Co.

Gordon, Richard. 1990. The Veil of Power: Emperors, Sacrificers and Benefactors. In Pagan Priests. Edited by Mary Beard and John North. Ithaca: Cornell University Press, ISBN 0-8014-2401-1.

Kennedy, George A. 1984. New Testament Interpretation through Rhetorical Criticism. Chapel Hill: University of North Carolina Press.

King, Charles. 2003. The Organization of Roman Religious Beliefs. Classical Antiquity 22: 275-312. [CrossRef]

Linder, M., and John Scheid. 1993. Quand croire c'est faire: le problème de la croyance dans la Rome ancienne. Archives de Sciences Sociales des Religions 81: 47-62. [CrossRef]

Mackey, Jacob. 2009. Rethinking Roman Religion: Action, Practice and Belief. Ph.D. dissertation, Princeton University, Princeton, NJ, USA.

McLuhan, Marshall. 1964. Understanding Media: The Extensions of Man, 2nd ed. New York: New American Library.

Naiden, Fred S. 2013. Smoke Signals for the Gods: Ancient Greek Sacrifice from the Archaic through the Roman Periods. Oxford: Oxford University Press, ISBN 978-0-19-991640-5.

Naiden, Fred S., and James B. Rives. 2016. Sacrifice. Oxford Bibliographies. Available online: http:/ / www.oxfordbibliographies.com/abstract/document/obo-9780195389661/obo-97801953896610209.xml?rskey=Z199Ef\&result=4\&q=Sacrifice\#firstMatch (accessed on 14 December 2018). [CrossRef]

Nock, Arthur Darby. 1933. Conversion: The Old and the New in Religion from Alexander the Great to Augustine of Hippo. London: Oxford University Press.

Nongbri, Brent. 2013. Before Religion: A History of a Modern Concept. New Haven: Yale University Press, ISBN 97800-300-15416-0.

North, John A. 2000. Roman Religion. Greece \& Rome New Surveys in the Classics no. 30. Oxford: Oxford University Press, ISBN 019-922433-1.

Patterson, Jane Lancaster. 2015. Keeping the Feast: Metaphors of Sacrifice in 1 Corinthians and Philippians. Atlanta: Society of Biblical Literature Press, ISBN 978-0-88414-065-8.

Peirce, Charles S. 1998. The Essential Peirce: Selected Philosophical Writings, Volume 2 (1893-1913). Edited by the Peirce Edition Project. Bloomington: Indiana University Press, ISBN 0-253-33397-0.

Price, Simon R. F. 1984. Rituals and Power: The Roman Imperial Cult in Asia Minor. Cambridge: Cambridge University Press, ISBN 052131268X.

Rives, James B. 2003. Magic in Roman Law: The Reconstruction of a Crime. Classical Antiquity 22: $313-39$. Reprinted with an update in Oxford Readings in the Religious History of the Roman Empire. Edited by J. A. North and S. R. F. Price. Oxford: Oxford University Press (2011), pp. 71-108. ISBN 9780199567348

Rives, James B. 2005. Christian Expansion and Christian Ideology. In The Spread of Christianity in the First Four Centuries: Essays in Explanation. Edited by William V. Harris. Leiden: Brill, pp. 15-41. ISBN 9004147179.

Rives, James B. 2011a. The Persecution of Christians and Ideas of Community in the Roman Empire. In Politiche religiose nel mondo antico e tardoantico: Poteri e indirizze, forme del controllo, idee e prassi di tolleranza. Atti del Convegno internazionale di studi (Firenze, 24-26 settembre 2009). Edited by Giovanni Alberto Cecconi and Chantal Gabrielli. Bari: Edipuglia, pp. 199-217. ISBN 9788872286227. 
Rives, James B. 2011b. Religious Choice and Religious Change in Classical and Late Antiquity: Models and Questions. ARYS: Antigüedad, religiones y sociedades 9: 265-80.

Rives, James B. Forthcoming a. Animal Sacrifice and Euergetism in the Hellenistic and Roman Polis. In The Economy of Roman Religion. Edited by Claudia Moser and Christopher Smith. Special issue, Religion in the Roman Empire 5.1.

Rives, James B. Forthcoming b. Roman Empire and Roman Emperor: Animal Sacrifice as an Instrument of Religious Convergence. In Religious Convergence in the Ancient Mediterranean. Proceedings of the Conference "Religious Convergence in the Ancient Mediterranean", 23-26 June 2016, Palermo, Italy. Edited by Billie Jean Collins and Sandra Blakely. Atlanta: Lockwood Press.

Rüpke, Jörg. 2014. From Jupiter to Christ: On the History of Religion in the Roman Imperial Period. Oxford: Oxford University Press, ISBN 9780198703723.

Schultz, Celia E. 2016. Roman Sacrifice, Inside Out. Journal of Roman Studies 106: 58-76. [CrossRef]

Smith, Jonathan Z. 1993. Map Is Not Territory: Studies in the History of Religions. Leiden: Brill, ISBN 0-226-76357-9. First published 1978.

Stowers, Stanley K. 2011a. Kinds of Myth, Meals and Power: Paul and the Corinthians. In Redescribing Paul and the Corinthians. Edited by Ron Cameron and Merrill P. Miller. Atlanta: Society of Biblical Literature Press, pp. 105-49. ISBN 978-1-58983-528-3.

Stowers, Stanley K. 2011b. Does Pauline Christianity Resemble a Hellenistic Philosophy? In Redescribing Paul and the Corinthians. Edited by Ron Cameron and Merrill P. Miller. Atlanta: Society of Biblical Literature Press, pp. 219-43. ISBN 978-1-58983-528-3.

Stowers, Stanley K. 2011c. The Religion of Plant and Animal Offerings Versus the Religion of Meanings, Essences and Textual Mysteries. In Ancient Mediterranean Sacrifice. Edited by Jennifer Wright Knust and Zsuzsanna Várhelyi. Oxford: Oxford University Press, pp. 35-56. ISBN 0199738963.

Stroumsa, Guy G. 2005. La Fin du sacrifice: Les mutations religieuses de l'Antiquité tardive. Paris: Odile Jacob, ISBN 2-7381-1634-5.

Tomson, Peter J. 1990. Paul and the Jewish Law: Halakha in the Letters of the Apostle to the Gentile. Assen: Von Gorcum, ISBN 90-232-2490-6.

Ullucci, Daniel. 2015. Sacrifice in the Ancient Mediterranean: Recent and Current Research. Currents in Biblical Research 13: 388-439. [CrossRef]

Wendt, Heidi. 2016. At the Temple Gates: The Religion of Freelance Experts in the Roman Empire. New York: Oxford University Press, ISBN 9780190267148.

Whitehouse, Harvey. 2004. Modes of Religiosity: A Cognitive Theory of Religious Transmission. Walnut Creek: Alta. 